\title{
DŹWIĘK I ZNACZENIE SŁOWA W POEZ]I JULIANA TUWIMA DLA DZIECI
}

\section{URSZULA KOLBEROVÁ}

\section{SOUND AND MEANING OF WORDS IN JULIAN TUWIM'S POETRY FOR CHILDREN}

ABSTRACT The article on the borderline of literature, linguistic and pedagogy focuses on poetry for youngest by Julian Tuwim. The article also shows how important the sound and the meaning of the word are in the development of speech, which Tuwim uses masterfully in his work. The article also presents some of the phraseologisms that appeared in Tuwim's poems for children.

KEY WORDS Julian Tuwim, poetry for children, meaning of word, sound of word, idiomatology

CONTACT urszula.kolberova@osu.cz 
Czasy przed epoką pozytywizmu nie były specjalnie przychylne poezji dla dzieci. Popularnością najczęściej cieszyły się np. bajki moralizatorskie Ignacego Krasickiego, bardziej znane były też utwory Izabeli Czartoryskiej, Klementyny Hoffmanowej czy Maksymiliana Popławskiego oraz utwory zagraniczne. Utwory te, w głównej mierze wytykały różnego rodzaju wady i przywary, i raczej nie były adresowane do najmłodszego czytelnika, ale nieco starszych dzieci lub nawet młodzieży. Nieco później podwaliny pod polską poezję dla dzieci stworzyli w czasach romantyzmu Stanisław Jachowicz, a w czasach pozytywizmu Maria Konopnicka. Chociaż nie można umniejszać wkładu w rozwój literatury dla najmłodszych wyżej wymienionych, to można stwierdzić, że dopiero Julian Tuwim pokazał, jaka może i powinna być poezja dla dzieci. Poezję tę trafnie scharakteryzował Bogusław Żurakowski (Żurakowski 1999: 11):

„Poezja dla dzieci Juliana Tuwima wywodzi się z okréslonej filozofii, która jest poszukiwaniem źródet poetyckiego świata w stowie-przedmiocie, w dźwiękowej magii, co po trosze przypomina rosyjskich futurystów."

Zatem celem niniejszego artykułu jest przybliżenie poezji Juliana Tuwima w twórczości dla małego odbiorcy. W szczególności rozważania zawarte w tym artykule skupią się na warstwie brzmieniowej, znaczeniowej oraz frazeologicznej wierszyków dla dzieci tego autora.

Wiersze dla dzieci powstawały w dojrzałym okresie twórczości poety. Są to wiersze pełne dowcipu i komizmu, czasem towarzyszy im absurd. Poeta często w pobłażliwy sposób wyśmiewa przywary i ujemne cechy charakteru, niektóre wierszyki zawierają ciekawy morał lub pouczenie, inne są źródłem wiedzy o otaczającym dziecko świecie.

Są to także wiersze, w których dźwięk i znaczenie odgrywają bardzo ważną rolę, ponieważ właśnie warstwa brzmieniowo-znaczeniowa jest często źródłem komizmu w poezji dla małego odbiorcy, uwaga dziecka skupia się głównie wokół dźwięków mowy, a także wokół ich znaczenia. To właśnie Tuwim, a po nim Jan Brzechwa, w oryginalny sposób rozwinęli formy zabawy poetyckiej plynącej z gry znaczeniem oraz brzmieniem słowa. Przypomnieć wystarczy na przykład takie wiersze jak Lokomotywa, Ptasie radio czy O panu Tralalińskim. Tuwim w wierszach dla dzieci daje prawdziwy upust swojej fantazji słowotwórczej i z dużą precyzją wykorzystuje warstwę brzmieniową i znaczeniową.

O tym, jak ważne w nauce języka macierzystego od pierwszych chwil życia dziecka są dźwięki mowy, zwrócił uwagę Robert Skoczek (Skoczek 2010: 477-478):

„Już $w$ tonie matki ptód styszy wysokie częstotliwości jej głosu wraz z wszelkimi odgtosami fizjologicznymi. To one już po narodzinach dziecka są dla niego jednym z głównych elementów identyfikacji rodzicielki. [...] Badania Alfreda Tomatisa ijego wspótpracowników dowodza, jak często niedoceniana jest rola tzw. dojrzewania dźwiękowego, które jest jednym z istotnych komponentów w rozwoju ogólnym każdego człowieka. Jean Piaget w swoim podejściu holistycznym i szczególnie w pierwszych dwóch fazach rozwoju poznawczego dziecka podkreśla, że przyswajanie jezyka (LI) równolegle i w zharmonizowany sposób przebiega z innymi procesami przygotowującymi dziecko do późniejszego życia w społeczeństwie. Poszczególne elementy tych złożonych procesów wspomagaja się nawzajem, czyniąc przez to akwizycję języka wielokanałowa $i$ intensywniejszą. Również w przypadku L1 opanowanie fonologicznego systemu jezykowego rozciaga się na wiele lat. Opanowanie artykulacji trudniejszych fonów i zbitek głosek zamyka siępod koniec szóstego roku życia dziecka". 
Z powyższego fragmentu wynika, że właśnie w najwcześniejszych latach życia dziecka uczy się ono poprawnej wymowy, artykulacji, przyswajając otaczające je dźwięki mowy. Ze względu na możliwości percepcyjne najmłodszych dzieci Tuwim bardzo trafnie przyciąga uwage najmłodszych słuchaczy poprzez formowanie swojego warsztatu twórczego wokół warstwy brzmieniowej.

Zapewne najbardziej znanym wierszem Tuwima dla dzieci jest Lokomotywa. W wierszu tym autor dokonał wprost mistrzowskiego zrytmizowania tekstu. Bogusław Żurakowski mocno podkreśla rolę rytmu mówiąc, że „awansuje on w poezji dla dzieci do pierwszorzędnej wewnątrztekstowej funkcji" (Żurakowski 1999: 49).

Do taktu turkoce i puka, i stuka to:

Tak to to, tak to to, tak to to, tak to to.

(Lokomotywa, w. 44-45.)

Melodia i rytm podczas czytania tego wiersza wywołują w podświadomości wrażenie taktowego stukotu kół, wyraźnie odczuwamy odgłosy jadącego pociągu. Wyczuwalny rytm, choć już nie $\mathrm{w}$ ty samym stopniu, co w Lokomotywie, występuje również $\mathrm{w}$ innym wierszu, mianowicie w Okularach, a to dzięki temu, iż został on napisany prawidłowym trochejem.

W Lokomotywie występują również liczne aliteracje oraz powtórzenia tych samych spółgłosek i samogłosek. Tak więc na początku lokomotywa „stoi i sapie”, później „dyszy i dmucha”, a żar z „rozgrzanego jej brzucha bucha”. Tak uwyraźniona strona brzmieniowa sprawia, że dziecko łatwiej zapamiętuje tekst, łatwiej przypomina sobie odgłosy lokomotywy. Co więcej, obecne są tu także elementy wyliczanki, kiedy to dochodzi do wynotowania zawartości poszczególnych wagonów, dalej występują liczne powtórzenia, które często spotykane są w twórczości Tuwima nie tylko w wierszykach dla dzieci:

A dokąd? A dokąd? A dokąd? Na wprost.

Po torze, po torze, po torze przez most.

(Lokomotywa, w. 40-41.)

Elementy wyliczanki spotykamy nie tylko w najbardziej kojarzonej przez dzieci Lokomotywie, ale również w innych wierszach: Warzywach, Ptasich plotkach, Abecadle, Tańcu czy W aeroplanie:

Wielkie góry-jak kupki piasku,

Wielkie drzewa-jak krzaczki w lasku,

Rzeki-srebrne wstążeczki,

Łąki-zielone chusteczki.

(W aeroplanie, w. 39-42.)

Elementy wyliczanki pozwalają dziecku łatwiej uporządkować pewną rzeczywistość, pokazują ilość, mnogość czegoś, inne pomagają małym dzieciom w nauce liczenia. Niektóre wyliczanki natomiast odwrotnie - wyzwalają z rygorów prawdopodobieństwa, poetycka wyobraźnia stwarza nowe i nieznane światy ${ }^{1}$. Tak jest na przykład w wierszyku Dyzio Marzyciel, który wylicza, w jakie pyszności, mogłyby się zamienić codzienne, realne rzeczy, takie jak niebo czy

1 http://www.qlturka.pl/czytelnia,literatura,ene_due_like_fake_\%E2\%80\%93_czyli_o_wyliczankowych_wierszach_dla_dzieci,9062.html. [17.12.2020] 
obłoki. Odnajdujemy tu swobodne dziecięce fantazjowanie, swoisty bunt przeciw logicznie ułożonemu światu, humor.

W swojej twórczości dla dzieci Julian Tuwim chętnie korzystał także z wykrzykników. Na przykład w Lokomotywie wykrzykniki dźwiękonaśladowcze w zdaniach oznaczających czynność czasami występują w funkcji orzeczenia „buch”, „uch”, „puff”, „uff” lub orzeczenie uzupełniają: „bucha buch-buch”. Wykrzykniki trafnie posłużyły tu do wyrażenia i zilustrowania strony dźwiękowej, emocji, rozkazów i intencji mówiącego. Wykrzykniki są bliskie spontanicznej mowie małych dzieci, które nie potrafią jeszcze nazwać danego stanu rzeczy czy zjawiska bądź użyją ich do opisu danego zdarzenia. Bardzo łatwo o odczytanie ich znaczenia, dlatego wykrzykniki to jedne z pierwszych wyrazów i części mowy, które przyswaja sobie dziecko, budując tak od podstaw swój system słownikowy. Według Tadeusza Milewskiego (Milewski 2004: 58-59):

„System słownikowy jezyka jest obrazem świata, który tradycja spoteczna narzuca jednostkom. Nasze wrażenia zmystowe porządkujemy wedle cech wprowadzonych przez ten system, tak aby każdy zespót wrażeń móc umieśsić wobrębie klasy objętej przez ten wyraz. System stownikowy ustala się w dzieciństwie. Wyrazy narzucają dziecku pewien wybór cech, na których podstawie przeprowadza ono klasyfikację doznanych wrażeń. W ten sposób zdobywa sobie dziecko schemat porzadkowania świata. Język wspótpracuje wówczas $w$ zdobyciu, rozczłonkowaniu $i$ uporządkowaniu przedstawień świata, które bez niego inaczej by sięułożyty. [...]

Raz ustalony system stownikowy staje się obrazem świata, w którym się obracają wszyscy członkowie danego spoteczeństwa i dzięki wtaśnie wspólności tego obrazu moga się ze soba porozumiewać. Dokonuje się to na podstawie skomplikowanego przekładania znaków jednego systemu na znaki systemu innego, co nazywamy przekodowaniem z jednego kodu na drugi. Zaczyna się od tego, że wyrażenia zmystowe osoby mówiącej zostają przekodowane na wyraz obejmujacy obraz akustyczny i zwiazane z nim przedstawienie. W wyniku jednak tej operacji powstaje właściwie nowy wyraz, który wchodzi w sklad tekstu budowanego przez nadawce. Ten nowy wyraz występujący w tekście ma pewne wspólne cechy z wyrazem istniejącym w systemie, który reprodukuje".

W utworach Tuwima dla dzieci występuje także w różnych postaciach onomatopeja, czyli dźwiękonaśladowczość jakże często spotykana $\mathrm{w}$ języku małych dzieci, które nie znają jeszcze wszystkich potrzebnych wyrazów języka ojczystego. W wierszykach Tuwima onomatopeja występuje raz jako pojedynczy wyraz dźwiękonaśladowczy: „gwizd”, „świst”, „buch”, „brzęk”, innym z kolei razem jako całe zdanie. Na przykład w wierszyku opisującym piękno przyrody poprzez personifikację i opis igraszek dwóch wiatrów w utworze o tej właśnie nazwie Dwa wiatry powtarzający się wers:

Liście pieścit i szeleśsit

(Dwa wiatry, w. 4.)

lub w Lokomotywie wers:

Ruszyta maszyna po szynach ospale

(Lokomotywa, w. 37.) 
jest zinstrumentalizowany za pośrednictwem sekwencji głosek [̌̌̀y], które mają przypominać odgłos powstającym przy wydostaniu się pary z lokomotywy.

Autorowi Lokomotywy nie była obca ani echolalia, czyli powtarzanie jednakowych lub podobnie brzmiących zespołów głoskowych dla podkreślenia melodyjności i rytmiczności tekstu, ${ }^{2}$ którą wykorzystał w wierszu O panu Tralalińskim. Wierszyk ten osnuty jest na powtarzalności dźwięku „trala”. Owo „trala” wykorzystuje cechę przedrzeźniania, która występuje w mowie dzieci. Zarazem staje się ona podstawą do tworzenia rytmu utworu i komizmu. A więc, gdy podniesie pan Tralalisław swą „pałeczkę-tralaleczkę”, wszyscy zgromadzeni, czyli „Tralalona”, „Tralurka”, „Tralalinek”, „Tralalesek”, „Tralalotek” i „Tralalużka” zgodnie śpiewają: trala trala tralalala, trala trala tralalala, by po chwili do całego grona dołączyli „Tralalofer”, „Tralalarka”, „Tralalówka”, a nawet myszka „Tralaliszka”. Nie trudno odczytać znaczenie poszczególnych „Trala-osób", jednak dziecko zmuszone jest do wysiłku intelektualnego i skojarzenia końcowych sylab wyrazów, w których ukryty jest ich sens, z poszczególną osobą czy zwierzęciem.

Pokaz prawdziwego koncertu i połączenia świata przyrody ze światem techniki, tworząc $\mathrm{w}$ ten sposób sytuację absurdu, daje Tuwim w wierszyku Ptasie radio. Ten prawdziwy koncert odwołuje się, według słów Broniewskiej (Broniewska 1938: 4), do czarodzieja doktora Dolittle’a, który rozumiał mowę zwierząt. W mistrzowski sposób została wykorzystana onomatopeja i elementy wyliczanki, ptaszki nie tylko oczywiście ćwierkają, ale świszczą, kwilą, a nawet „pitpilaszą” i „pitpilą”. Jak zauważa Krystyna Pisarkowa (Pisarkowa 1983: 66):

„nie wszystkie onomatopeje polegaja na powtarzaniu jednego odgłosu [...] ale ponieważ same odgłosy naśladowane często się powtarzaja, typowe onomatopeje są parami, trójkami i parami par, oczywiście rymujących sie, powtarzanych dźwięków".

Ptasią audycję Tuwim rozpoczyna umiejętnie przenosząc na kartki śpiew słowika:

„Halo! O, halo lo lo lo lo

Tu tu tu tu tu tu

Radio, radijo, dijo, ijo, ijo"

Na co zaczyna ćwierkać oburzony wróbel:

„Ćwir ćwir świrk!

Świr świr ćwir!"

(Ptasie radio, w. 28-30., 38-39.)

Wszystkie te wyrazy mają charakter imitacyjny i naśladują spontaniczną dziecięcą twórczość słowną.

Tuwim w wierszach dla najmłodszych w bogaty i wspaniały sposób wykorzystał figurę paraetymologiczną, która również oparta jest na warstwie brzmieniowej, jak i znaczeniowej. Przykładem takiego zabiegu jest wiersz Figielek, w którym Tuwim naśladuje żartobliwe kreacje słowne, dostosowuje się do swoistego humoru dzieci, jednocześnie ucząc małych odbiorców wrażliwości na komiczne walory słowa. Tak więc dowiadujemy się z Figielka o tym, że:

2 http://gacek33online.republika.pl/10teoria/o5jezyk.html. [27.12.2020] 
„Raz się komar z komarem przekomarzać zacząt

Mówiąc, że widziat raki, co się winkiem raczą.

Cietrzew się zacietrzewit styszac takie stowa,

Sep się zasępit, osowiata sowa".

(Figielek, w. 1-4.)

Takie wierszyki, w których na pozycjach klauzulowych znajdują się słowa i wyrażenia homonimiczne, Jerzy Ficowski nazywa „rymowankami dziwnymi” bądź „bajdurkami” (Balcerzan 1983: 145). Mały odbiorca w pierwszym rzędzie zwraca uwagę na komizm słowny i podobieństwo wyrazów, które przyciągają jego uwagę, poprzez co odkrywa prawdziwe znaczenie czasowników.

W wierszach dla dzieci szczególnie ważną rolę odgrywa przede wszystkim rym. Jak zauważa Jan Brzechwa, rym skupia uwagę dziecka, a elementy dźwiękowe wybijają się na czoło także dlatego, że w samym dziecku tkwi skłonność do rymowania (Brzechwa 1955: 165). Toteż najlepiej dla małego odbiorcy, gdy rymy są sąsiadujące. Tuwim stara się spełniać owo założenie jak najwierniej i rzeczywiście w jego twórczości dla dzieci przeważająca ilość wersów jest zrymowana parzyście.

W swojej twórczości dla dzieci autor Lokomotywy wykorzystał także warstwę frazeologiczną i znaczenie jednostek frazeologicznych. Choć związki frazeologiczne nie wysuwają się w wierszach Tuwima na pierwsze miejsce, jak warstwa brzmieniowa, są jednak obecne w twórczości poety.

Tuwim wykorzystuje na przykład porównania, które służą do lepszego zilustrowania, przybliżenia danego przedmiotu czy zjawiska, uwydatnienia ich cech. Dziecko kojarzy dwa przedmioty czy zjawiska i podobieństwo ich cech wzajemnych, w prosty sposób dowiaduje się, że „coś jest jak coś”. Przykładem takiego zabiegu może być wierszyk Pycha, w którym dowiadujemy się, że:

A czapka na niejjak żerdź

(Pycha, w. 4.)

Innym przykładem jest terlikanie wróbla, który porównuje śpiew słowika do koncertu Jana Kiepury $^{3}$ i ćwirka, że słowik:

Daje koncert jak kiepurka!

(Ptasie radio, w. 43.)

Oczywiście dziecko raczej nie skojarzy „kiepurki” z osobą Jana Kiepury, jednak z pewnością zapyta rodzica o znaczenie tego słowa lub sam rodzic, nawet niepytany, pospieszy z wyjaśnieniem. Prawdziwa plejada porównań pojawia się w wierszyku $W$ aeroplanie, gdzie:

Śmigło kręci sięjak fryga

Wielkie góry-jak kupki piasku,

Wielkie drzewa-jak krzaczki w lasku,

Jeziora-jakdonice,

Pociagi-jakgasienice,

Ludzie-jak mrówki,

Polak C., http://www.goldenline.pl/forum/70477/jak-w-prl-cenzurowano-bajki. [27.12.2020] 
Krowy-jak boże krówki

(W aeroplanie, w. 23., 39-40., 45-48.)

Niektóre związki frazeologiczne i ich znaczenie właściwe i dosłowne stają się podstawą komizmu i absurdu w wierszykach. Tak może być w wierszyku o głupim Gabrysiu, który oprócz innych absurdalnych i bezcelowych rzeczy:

... drwa do lasu nosit.

(Gabryś, w. 6.)

Innym razem komizm w wierszyku Trudny rachunek wywołują kaczki, które „wracają gęsiego" (w. 24.).

Tuwim w swojej twórczości dla dzieci wykorzystuje również utarte związki frazeologiczne, ucząc tak małych odbiorców nowych znaczeń danych wyrażeń i poszerzając zasób słownictwa dziecka. Dzięki lekturze wierszy Tuwima dziecko utrwala przykładowo następujące związki frazeologiczne:

... drwa do lasu nosit (Gabryś, w. 6.) - nosić drewno do lasu - znaczenie: ,niepotrzebnie się trudzić."

Kto by sobie głowę łamał (Zosia Samosia, w. 32.) - łamać sobie głowę - znaczenie: ,zastanawiać się nad czymś intensywnie, starać się coś rozwikłać, próbować znaleźć wyjście z trudnej sytuacji (Bąba - Liberek 2002: 353) ,rozmyślać, szukać odpowiedzi'.

Wystąity na Jerzyka siódme poty (Słówka i słufka, w. 24.) - wyciskać z kogoś siódme poty - znaczenie: ,zmuszać się do bardzo dużego wysiłku'.5

Co świtem piszczy w trawie (Ptasie radio, w. 6.) - wiedzieć co w trawie piszczy - znaczenie: ,dobrze orientować się w sytuacji, trafnie przeczuwać to, co może się zdarzyćć (Bąba-Liberek 2002: 580).

A po piate przez dziesiąte (Ptasie radio, w. 14.) - piąte przez dziesiąte - znaczenie: ,bardzo mało, słabo, trochę, z grubsza, chaotycznie' (Bąba-Liberek 2002: 556).

Na głowie staną świat (W aeroplanie, w. 56.) - coś stoi na głowie - znaczenie: ,wyprawiać brewerie, awantury, dokazywać, swawolić (Bąba-Liberek 2002: 181), coś dzieje się wbrew przyjętym regułom lub oczekiwaniom'. ${ }^{6}$

Klnie starego na czym świat stoi (Bajka o rybaku i rybce, w. 84.) - kląć na czym świat stoi - znaczenie: ,kląć, złorzeczyć bardzo mocno, gwałtownie, w wielkim zdenerwowaniu' (Baba-Liberek 2002: 278).

Czy się, babo, szaleju objadłaś? (Bajka o rybaku i rybce, w. 125.) - najeść się szaleju, znaczenie: ,mówić, zachowywać się nieprzytomnie, nieopanowanie, szaleć, bredzić."7

Czasami mały odbiorca od razu może domyślić się znaczenia danego frazeologizmu, zwłaszcza w przypadku wystąpienia łączliwych związków frazeologicznych, w których poszczególne

4 http://megaslownik.pl/slownik/polsko_angielski/3548,powiedzenie+nosić+drzewo+do+lasu+niepotrzebnie +się+trudzić. [27.12.2020]

5 https://wsjp.pl/index.php?id_hasla=40140\&ind=o\&w_szukaj=potem. [27.12. 2020]

6 https://wsjp.pl/index.php?id_hasla=49323\&ind=o\&w_szukaj=co\%C5\%9B+stoi+na+g\%C5\%82owie. [27.12.2020]

7 http://sjp.pwn.pl/haslo.php?id=60037. [27.12.2020] 
składniki są w dużym stopniu powiązane znaczeniowo, a o łączliwości decyduje częstość użycia takiego połączenia oraz bliska łączność treściowa składników, dalej w przypadku, kiedy chodzi o takie związki wyrazowe, których znaczenie wynika z sumy znaczeń komponentów, przy czym przynajmniej jeden z nich ma osobliwe, nietypowe znaczenie (Bąba 1986: 8-9) lub gdy sens frazemu mieści się w zakresie znaczenia wyrazu nadrzędnego (dominującego), a także w przypadku wystąpienia wyrażenia przyimkowego. Przykładem mogą być:

Aż się miotle na płacz zbiera (Taniec, w. 14.) - zbierać się na płacz

Parskną śmiechem caty sad (Dwa wiatry, w. 16.) - parsknąć śmiechem

Oj, Grzesiu, kłamiesz! Lepiej powiedz po dobroci! (O Grzesiu kłamczuchu i jego cioci,

w. 5.) - zrobić coś po dobroci

No, słowo daję! (O Grzesiu kłamczuchu ijego cioci, w. 8.) - dać komuś słowo

Natomiast w wierszyku Tuwima pt. Skakanka odnajdujemy sztandarowe przysłowie znane każdemu polskiemu dziecku Żeby kózka nie skakała, to by nóżki nie złamała (w. 1-2.).

Podsumowując, możemy stwierdzić, że wszystkie wierszyki dla dzieci, które wyszły spod pióra Juliana Tuwima, mają zabawny i żartobliwy charakter, czasami Tuwim wykorzystuje funkcję moralizatorsko-dydaktyczną, w wesoły sposób ganiąc niepoprawne zachowania. Tuwim poezji przeznaczonej dla małego odbiorcy nigdy nie traktował jako ułatwionej. Z takim samym wysiłkiem, jak w pozostałej części swej twórczości, z taką samą precyzją, a być może jeszcze bardziej wzmożoną, stosuje różne chwyty poetyckie, zabawia się słowem i znaczeniem, stosuje liczne zestawienia dźwiękowe. Warstwa brzmieniowa, jak u nikogo innego, skupia uwagę małego odbiorcy, towarzyszy jej humor, komizm zbliżony nawet do absurdu. Humor wykorzystany został również we frazeologizmach, które nie są skomplikowane i w naturalny sposób wzbogacają zasób słownikowy dziecka.

\section{SOUND AND MEANING OF WORDS IN JULIAN TUWIM'S POETRY FOR CHILDREN}

SUMMARY This article focuses on Tuwim's poetry for children and it presents sound of word, semantic and idiomatology side. The article brought closer examples of alliteration, onomatopoeia, exclamation marks, counting, rhythmical line of text, which are appearing in the works of Tuwim children. The compounds were also some of the idioms, which are present in Tuwim's poetry for children.

\section{LITERATURA}

I Balcerzan E., 1983, Odbiorca w poezji dla dzieci, Literatura i podkultura dzieci i młodzieży, red. J. Cieślikowski i R. Waksmund, Wrocław, s. 143-173.

I Bąba S., 1986, Twardy orzech do zgryzienia, czyli o poprawności frazeologicznej, Poznań.

I Bąba S. - Liberek J., 2002, Stownik frazeologiczny wspótczesnej polszczyzny, Warszawa.

I Brzechwa J., 1955, O poezji dla dzieci, „Twórczość”, 4., s. 163-170.

I Broniewska J., 1938, Tuwim dla dzieci, „Wiadomości Literackie”, 14, s. 4. 
I Kuczyńska-Koschany K., 2012, „Lokomotywa” Tuwima: wariacje i konteksty (od wiersza dla dzieci do wiersza o Zagładzie), „Polonistyka”, nr 1, s. 6-13.

I Kuszak K., 2014, Świat związków frazeologicznych w języku dziecka. Inspiracje teoretycznebadania-implikacje praktyczne, Poznań.

I Milewski T., 2004, Językoznawstwo, Warszawa.

I Ostasz M., 2008, Od Konopnickiej do Kema: studium wiersza pajdialnego, Kraków.

I Ostasz M. - Michalik M., 2016, Logopedyczny wiersz pajdialny, Kraków.

I Ostasz M., 2017, Wiersze jako scenariusze ćwiczeń językowych, „Logopedia”, t. 46, s. 73-90.

I Pisarkowa K., 1983, Wyliczanki polskie, Literatura i podkultura dzieci i młodzieży, red. J. Cieślikowski i R. Waksmund, Wrocław, s. 55-84.

I Skoczek R., 2010, Curriculum fonetyczne a ramy czasowe, Literaturoznawstwo, językoznawstwo i kulturoznawstwo jako plaszczyzny przekazu we wspótczesnej glottodydaktyce, red. J. Knieja, T. Zygmunt, Ł. Brzana, Lublin, s. 477-486.

I Sokólska U., 2019, Autotautogram, czyli raz jeszcze w sprawie zabaw Juliana Tuwima brzmieniową warstwą leksyki, „Studia Językoznawcze. Synchroniczne i diachroniczne aspekty badań polszczyzny", t. 18, s. 229-239.

I Szóstak A., 1999, Organizacja warstwy brzmieniowej tekstu w wierszach Juliana Tuwima i Jana Brzechwy dla dzieci, „Studia i Materiały Wyższej Szkoły Pedagogicznej w Zielonej Górze. Filologia Polska", z. 10, s. 113-122.

I Tuwim J., 1954, Wiersze dla dzieci, Warszawa.

I Żurakowski B., 1999, W świecie poezji dla dzieci, Kraków.

\section{Źródła internetowe}

I Polak C., http://www.goldenline.pl/forum/70477/jak-w-prl-cenzurowano-bajki. [27.12.2020]

I http://www.qlturka.pl/czytelnia,literatura,ene_due_like_fake_\%E2\%80\%93_czyli_o_ wyliczankowych_wierszach_dla_dzieci,9062.html. [17.12. 2020]

I http://gacek33online.republika.pl/10teoria/05jezyk.html. [27.12.2020]

I http://megaslownik.pl/slownik/polsko_ angielski/3548,powiedzenie+nosić+drzewo+do+lasu+niepotrzebnie+się+trudzić. [27.12.2020]

I https://wsjp.pl/index.php?id_hasla=40140\&ind=o\&w_szukaj=potem. [27.12.2020]

I https://wsjp.pl/index.php?id_hasla=49323\&ind=o\&w_ szukaj=co\%C5\%9B+stoi+na+g\%C5\%82owie. [27.12.2020]

I http://sjp.pwn.pl/haslo.php?id=60037. [27.12.2020] 